\title{
A socio-cultural model of Judean ethnicity: A proposal
}

\author{
Markus Cromhout \& Andries van Aarde* \\ Faculty of Theology \\ University of Pretoria
}

\begin{abstract}
This article focuses on the matter of Judean ("Jewish") ethnic identity during the first century CE. New Testament scholarship lacks an overall interpretive framework by which Judean identity can be understood. Appreciation of what informed the entire process of Judean ethnic identity formation in the first century, or at any period for that matter, is lacking. This lack of interpretive framework is rather acute in scholarship on the historical Jesus, where the issue of Judeanness ("Jewishness") is most strongly debated. A Socio-Cultural Model of Judean Ethnicity is developed, as being a synthesis of (1) Sanders' notion of covenantal nomism, but reappropriated to serve as an ethnic descriptor, (2) Berger and Luckmann's theories on the sociology of knowledge, (3) Dunn's "four pillars of Second Temple 'Judaism" and his "new perspective" on Paul, (4) cultural anthropology in the form of modern ethnicity theory, and lastly, (5) Duling's Socio-Cultural Model of Ethnicity. The proposed model is termed covenantal nomism. It is a pictorial representation of the Judean "symbolic universe" which, as an ethnic identity, is proposed to be essentially primordialist.
\end{abstract}

\section{INTRODUCTION}

It is supposed that one of the "Third Quest's" characteristic traits is to place emphasis on the "Jewishness" of Jesus. It also generally wants to place Jesus within "Judaism" and to view him as properly integrated into the "Judaism" of his day. Thus the "Third Quest" emphasizes the continuity between Jesus and his environment and assumes him to be an integral part of it (Du Toit 2001:100-109; Harrington 1987). Holmén (2001:150) explains that the "Third Quest" distinguishes itself from earlier phases of Jesus research "by viewing Jesus as profoundly Jewish, properly integrated into the Judaism of his time."

\footnotetext{
*This article is based on Markus Cromhout's PhD dissertation, entitled "The reconstruction of Judean ethnicity in Q". The dissertation was prepared under the supervision of Prof Dr Andries G van Aarde, Faculty of Theology, University of Pretoria (2006).
} 
But he also notes that on closer examination, such a view "reveals that there are some intricate difficulties involved here." He is in particular referring to the view that has developed over the past few decades that there was no orthodox Judaism in Jesus' day. Judaism was formative, or dynamic and there was an almost unlimited diversity and variety, or pluralism was commonplace. Holmén (2001:152-153) has noted the paradox: "We can actually determine what is 'profoundly Jewish' only if we use some kind of 'normative Judaism' as a yardstick." He further argues the "crucial problem of the 'Third Quest' seems to be that it is not the least clear what 'Jewishness' means. Indeed, judged on the basis of different scholarly pictures of Jesus it can mean almost anything" (Holmén 2001:154; emphasis added). Thus, to talk about Jesus' "Jewishness" has become widespread, but it is something quite void of real meaning.

Holmén (2001:158-159) suggests that it is possible to focus the analysis of the data on different elements, namely, on "what is common and what unites, and what is different and what separates." In this regard he draws attention to the strategies of "nominalism" and "essentialism". Nominalism accounts for the differences with regard to "Judaism". Essentialism looks at common characteristics of "Judaism", such as core belief and foundational metaphor, monotheism, covenant and ethnic exclusivism, and so forth. Holmén (2001:160) suggests that for Jesus-of-history research, "essentialism" is the appropriate strategy, although he does not find the term all that satisfying. He refers to scholars who have attempted in their own way to set some guidelines for something like basic or "common Judaism"; that is Dunn (the "four pillars" - see below), Sanders ("covenantal nomism" - see below) and Wright ("mainline", explained through the study of worldview, beliefs and hope). Holmén (2001:161) goes on to explain:

The guidelines for basic or common Judaism would not question the diversity of first-century Judaism, neither would they question Jesus' Jewishness. But the guidelines would enable us meaningfully to evaluate just how he was Jewish by justifying the positing of pictures of Jesus varying from the commonly Jewish to the marginally Jewish. We could again assess whether Jesus was, for example, profoundly Jewish or a 'different kind of Jew'.

Following Holmén's lead, we shall look at Dunn and Sanders' attempts at establishing guidelines for a "common Judaism" and eventually we will integrate their work into our own proposed model, drawing inspiration from Duling's (2005) Socio-Cultural Model of Ethnicity. This generic model lists, amongst other things, the cultural features to be on the look out for when analyzing the ethnic identity of a particular group of people (i e name, myths of 
common ancestry, shared "historical" memories, phenotypical features, land, language, kin, customs and religion).

There are scholars who are of the opinion that we cannot even speak of a "common Judaism". We should rather speak of "Judaisms". For example, Chilton \& Neusner (1995) argues that there was no single orthopraxy or law that governed life of all "Jews". The work such as produced by Dunn and Sanders is also criticized in that it focuses only on a small selection of theological elements that are claimed to be constitutive of Jewish identity. Space does not permit an elaborate discussion, but is the absolute insistence on "Judaisms" not taking the ancient data to an unnecessary extreme ${ }^{1}$ It is agreed that the approaches of Dunn and Sanders are limited, something which they themselves admit (see below), but it is our argument that their aim is warranted and their different approaches that concentrate on a few "theological" issues and on what is common and what unites, are a step in the right direction. Ethnicity theory informs us that religion is one cultural feature that contributes towards ethnic identity. In addition, in pre-modern eras a distinctive religion or vision of a world religion proved to be a very strong force in the persistence of ethnic identity (Smith 1994:716). The notions of Israel's God (monotheism), his election of Israel and gift of the Law, adherence to the Temple and the requirement to obey so as to maintain covenant status, elements variously emphasized by Dunn and Sanders respectively, most certainly qualify as a distinctive religion or vision of a religion. These elements were widely shared and for the greater part "Jews" had far more in common than what divided them (cf Stegemann \& Stegemann 1999:149-50).

The above suggests that if we approach first century Judaism, or as we shall prefer to call it, first century Judeanism as an ethnic identity, not merely

\footnotetext{
${ }^{1}$ We can elaborate on this by means of the following contrast. One can speak of "Judaisms" as you can speak of "Christianities". Perhaps it is possible then to speak of a "common Christianity", as Christians share many common beliefs and practices. By contrast, however, first century "Judaism" was something that present day Christianity is not - it was an ethnic identity, a unique cultural entity in addition to being a religious identity. And what Chilton and Neusner write of a particular "Judaism", can equally apply to "Judaism" as an ethnic identity. They speak of three necessary components of a religious system, for example of a specific "Judaism": 1) way of life; 2) world-view and 3) a theory of the social entity. Therefore, when it comes to "a Judaism", "a Judaic theory of the social order will always call its social entity 'Israel,' invariably will appeal to the Torah, and inevitably will link the main propositions of the theory to the Torah, whether through explicit, verbal exegesis, or through gestures or actions or rites that mirror or mimic those of the Torah, or through other media of cultural continuity ... The way of life of a Judaism finds its critical task in mediating between a way of living deemed natural and broadly accepted [!] and the special traits of the distinct social entity, that is, in defining 'we' as against 'they'" (Chilton \& Neusner 1995:42-43). But we must ask why this cannot be applied to all or most "Jews" as a distinct social entity, whose participants in most respects had "a way of living deemed natural and broadly accepted" and a common worldview derived from the Torah, and who would call their social entity Israel. Ethnicity theory (see below) in this regard also speaks of a "we" aggregative self-definition (and a "wethey" oppositional self-definition).
} 
as a loose collectivity of differing religious persuasions, the potential does exist for us to speak of a "common Judaism/Judeanism". In this respect the more "theological", even if limited, approach of Dunn and Sanders provides a good starting point. This does not eliminate the reality of diversity within "Judaism"/Judeanism. Even so, the overwhelming majority of "Jews"/Judeans (being peasant farmers living in villages and towns) were not members of any religious sect and would have adhered to the basics of "Jewish"/Judean religion and culture common to all. But, be they priests, Pharisees, Essenes, Sadducees, or peasant farmers, their wives and children included, they all would have been recognized - both from without and within - as "Jews"/Judeans, whether they had marginal status or not. We are speaking here of a collectivity of people who expressed their identity through a widely shared religion, but in addition to this, also a shared ancestry and history, customs, kinship, and attachment to the ancestral land of Israel.

The cultural features of land and kinship in particular are elements of identity which do not receive enough emphasis in the approaches of Dunn and Sanders. Focusing for now on the issue of land, a result is that they, as many scholars do, feel comfortable to speak of "Jews" and "Judaism", deemphasizing the important role that territorial rootedness in Judea played. As Pilch (1997) has argued, however, it is anachronistic to speak of "Jews" and

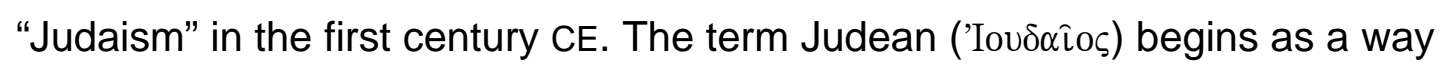
of identifying someone from Judea ('Iovo $\alpha$ í $\alpha$ ) (Josephus, Ant 11.173). ${ }^{2}$ Esler also points out that it was common practice in antiquity to name ethnic groups in relation to the territory from which they came. Referring to the Greeks and Romans, he writes that one "would expect them to connect ['Iovoøiol] with the

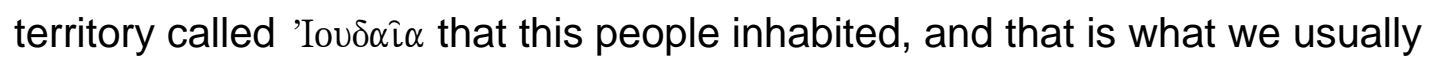
find" (Esler 2003:63). The attachment between the people and the land is even closer in Judean sources (Esler 2003:64-65). This article will from now on make use of the term "Judean(s)". For our purposes here a Judean refers to an "Israelite" inhabitant of Judea (and Palestine generally), a person who was a Judean by religion and culture and therefore had ethnic connections to

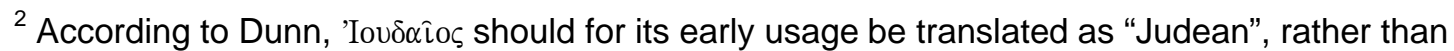
"Jew". He basically follows the argument of Cohen (1999:70-136; cf 1990:204-23) who stated

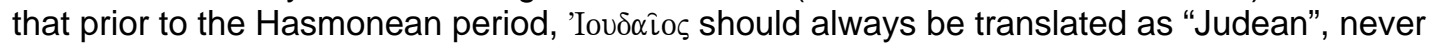
as "Jew". But there was a shift from a purely ethno-geographical term to one of a more "religious" significance, first evident in 2 Maccabees 6:6 and 9:17. Here for the first time

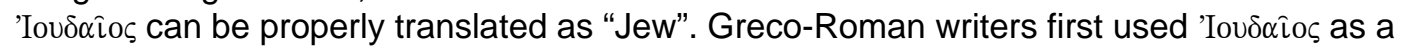
religious term at the end of the first century. Dunn (2003:262-263) nevertheless goes on to state that "even in later usage, referring, for example, to Jews long settled in the diaspora, the basic sense of 'the Jews' as the nation or people identified with the territory of Judea is still present."
} 
Judea and allegiance to its state religion (cf Duling, 2005, pp. 9-10 of 30). ${ }^{3}$

The religious-cultural system of Judeans is also properly called "Judeanism". ${ }^{4}$

In the pages that follow we are therefore also deliberately replacing "Jew(s)" and "Judaism" with "Judean(s)" and "Judeanism" when referring to or quoting from the work of scholars (when quoted, the replacement will appear in square brackets). This is by no means intended to be an anachronistic distortion of their positions. It should be remembered that they speak of "Jews" and "Judaism". Our replacement serves as a necessary economy and to illustrate that what these scholars wrote in reference to "Jews" and "Judaism" also holds true for what we are arguing in reference to "Judeans" and "Judeanism".

As already mentioned, we will look at Dunn and Sanders' attempts at establishing guidelines for a "common Judaism/Judeanism". We will integrate their work into our own proposed model, adapting Duling's generic model of ethnicity in order for it to serve as a guide when assigning content to Judean ethnic identity. In other words, the model must help us to answer what it meant, broadly speaking, to be Judean. This model, we suggest, will in some way assist in determining what "common Judeanism" involved, while it may also be used to investigate or compare the ethnic identity of various forms of sectarian Judeanism.

\section{COVENANTAL NOMISM}

Arguably, Sanders' notion of covenantal nomism has revolutionized our understanding of Palestinian "Judaism" (hereafter "Judeanism"). For a first century "Jew" (hereafter "Judean"), Israel's covenant relationship with God was basic, basic that is to the Judean's sense of national identity and the understanding of his/her religion. Sanders (1992:262) explains that "covenant" stands for God's grace in election ("getting in"), and "nomism" stands for the requirement of obedience to the law ("staying in"). Otherwise, Sanders explains covenantal nomism as follows: "(1) God has chosen Israel and (2) given the law. The law implies both (3) God's promise to maintain the election and (4) the requirement to obey. (5) God rewards obedience and punishes

\footnotetext{
${ }^{3}$ Dennis C Duling 2005. Ethnicity, Ethnocentrism, and the Matthean Ethnos. Biblical Theology Bulletin 35(4). (http://0- infotrac.galegroup.com.iinopac.up.ac.za/itw/infomark/ 628/813/76794221w5/purl ... 2005/12/07). Unpublished version: Duling, D C 2003. "Ethnicity, Ethnocentrism, and the Matthean Ethnos", paper presented at the 57th General Meeting of Studiorum Novi Testamenti Societas, Bonn, Germany 2003. Because of the electronic format, references to the published version correlate with page numbers in the above-mentioned http format. A "hard copy" of the 2005-published version in BTB was not available when this article was written.

${ }^{4}$ The terms "Judean" and "Judeanism" are also preferred by the BDAG (2000).
} 
transgression. (6) The law provides for means of atonement, and atonement results in (7) maintenance or re-establishment of the covenantal relationship. (8) All those who are maintained in the covenant by obedience, atonement and God's mercy belong to the group which will be saved." He adds: "An important interpretation of the first and last points is that election and ultimately salvation are considered to be God's mercy rather than human achievement" (Sanders 1977:422). Importantly, the emphasis is on maintaining your covenant relationship with God - obedience to the law was not thought of as a means of entering or attaining a special relationship with God. Dunn (1990:186) quotes Sanders' work in the following convenient manner in that covenantal nomism

\begin{abstract}
is the view that one's place in God's plan is established on the basis of the covenant and that the covenant requires as the proper response of man his obedience to its commandments, while providing means of atonement for transgression ... Obedience maintains one's position in the covenant, but it does not earn God's grace as such ... Righteousness in [Judeanism] is a term which implies the maintenance of status among the group of the elect.
\end{abstract}

(Sanders 1977:75, 420, 544)

Viewed from the perspective of ethnic identity, we can paraphrase/modify the above quote as follows: Covenantal nomism is the view that one's place in God's plan is established on the basis of the covenant, a covenant which in itself established Judean (or Israelite) ethnicity (= status of divine election). The covenant requires as the proper response from a Judean his/her obedience to the commandments, which will maintain his/her position as a (righteous) Judean within the covenant. Alternatively, the covenant provides also for means of atonement for transgression to maintain his/her status as a (righteous) Judean within the covenant. Righteousness in Judeanism is a term which implies the maintenance of status as a Judean among fellow Judeans who are the elect people of God.

Thus in broad terms, we suggest, it can be seen that covenantal nomism properly explains who is an ethnic Judean and who is not, and how it came to be that way. Here it is understood primarily in religious terms, however, since covenantal nomism is equivalent to divine election or "righteousness", or the maintenance of status in the sight of Yahweh. At the same time, Sanders admits that covenantal nomism does not cover the entirety of Judean theology or the entirety of Judeanism. 
It deals with the theological understanding of the constitution of God's people: how they get that way, how they stay that way. In terms of [Judeanism] as a religion, this leaves out a lot of details of what people did, though it requires analysis of why they thought that they should do what they did ... What it covers ... is crucial for understanding [Judeanism], which is a national religion and way of life, focused on the God of Israel and the people of Israel: God called them; being [Judean] consists of responding to that call.

(Sanders 1992:262-63; emphasis original)

From all of the above we can infer that covenantal nomism involves the existence of a two-way relationship. God called a particular people and in that process established a constitution or charter (= covenant as expressed through the Torah) of Judean ethnic identity. The people elected must respond to that call, and so give expression to that ethnic identity through obedience to the constitution. Differently put, God established Judean ethnic identity. A group of people respond(ed) by being Judean, in whatever way was deemed necessary. For our purposes therefore we deem it appropriate to redefine covenantal nomism as an ethnic descriptor. Seen from this view, we can speak of covenantal nomism as defining a "common Judeanism", where its religious or theological aspects become part of a greater whole. This also avoids the pitfall of "Judaisms/Judeanisms". Thus covenantal nomism, when redefined as an ethnic descriptor, can be understood as encapsulating the Judean "symbolic universe", containing more or less everything that typified Judean ethnic identity. Covenantal nomism was the Judean social construction of reality, a reality that took shape over several centuries of development. The point is this: our redefined covenantal nomism called into being, contained, shaped and defined Judean ethnicity. Also, on an anthropological and more concrete level, covenantal nomism is Judean ethnic identity - certain people translated that symbolic universe into everyday living. For our purposes our redefined covenantal nomism and Judean ethnicity are virtually synonymous in meaning.

\section{COVENANTAL NOMISM AS A "SYMBOLIC UNIVERSE"}

Our notion of the "symbolic universe" is drawing on the insights of Berger \& Luckmann (1967). To begin with, human beings exist within a social order, but it is a result of human production in the course of ongoing human externalization. This process occurs within the context of social interaction. All human activity is subject to habitualization. Habitualized actions produce institutions, which typify both individual actors and individual actions. As such, 
it forms "knowledge". As these institutions or knowledge is passed on from generation to generation, it acquires an objective quality: "This is the way that things are done", or, put in another way, it becomes the social construction of reality. This objective reality confronts the individual and into which a child is socialized. As such it is perceived as an external reality that exists outside of the individual (Berger \& Luckmann 1967:60).

The important thing, however, is "that the relationship between man, the producer, and the social world, his product, is and remains a dialectical one ... The product acts back upon the producer" (Berger \& Luckmann 1967:61). Thus externalization and objectification are followed by internalization. "Society is a human product. Society is an objective reality. Man is a social product" (Berger \& Luckmann 1967:61; emphasis original). In this manner "objective truths", which were established based on historical processes, are passed on from generation to generation in the course of socialization and so becomes internalized as subjective reality (cf Berger 1973:14).

The institutional order requires legitimation if it is to be transmitted to a new generation. "Legitimation not only tells the individual why he should perform one action and not another; it also tells him why things are what they are. In other words, 'knowledge' precedes 'values' in the legitimation of institutions" (Berger \& Luckmann 1967:94; emphasis original). One means of legitimation is where the entire institutional order is placed within a "symbolic universe". A symbolic universe is where

\begin{abstract}
all the sectors of the institutional order are integrated in an allembracing frame of reference, which now constitutes a universe in the literal sense of the word, because all human experience can now be conceived of as taking place within it. The symbolic universe is conceived of as the matrix of all socially objectivated and subjectively real meanings; the entire historic society and the entire biography of the individual are seen as events taking place within this universe.
\end{abstract}

(Berger \& Luckmann 1967:96; emphasis original)

The commonalities between our redefined notion of covenantal nomism as an ethnic identity and the idea behind the symbolic universe can immediately be perceived. Judeanism was quite distinct in its world-view. As Sanders (1992:50) explains:

It attempted to bring the entirety of life under the heading, 'Divine Law' [for our purposes read: it attempted to bring all human 
experience into a Judean symbolic universe, our redefined covenantal nomism]. As a religion, it was not strange because it included sacrifices, but because it included ethical, family and civil law as well.

Having been spared the modern reality of secularization, all aspects of Judean life were permeated with the divine and had a deeper significance. All aspects of life were under God and should be lived in accordance with God's will (cf Josephus, Apion 2.170-3).

Importantly, symbolic universes are social products with a history. "If one is to understand their meaning, one has to understand the history of their production" (Berger \& Luckmann 1967:98). For first-century Palestinian Judeanism, the character of its symbolic universe was primarily shaped by Israel's relationship with the land. They lost the land through the Babylonian exile. They regained it, but only partially, as they remained under foreign domination for most of their history. However, it was the Babylonian exile that provided the background for the shaping of the Torah, the primary reference for the Judean symbolic universe. The land was theirs as a perpetual inheritance, but it was the sins of Israel that caused them to lose control of it. Obedience and holiness were required, and along with hopes of restoration, as given through the prophets, it existed as important parts of that universe. The Judean symbolic universe could only become complete by Israel's obedience, restoration, and ownership of the land.

The symbolic universe is also nomic, or ordering in character. Everything is placed into its proper place, which also facilitates the formation of individual identity. This identity is dependant on the person's relationship with significant others, and the identity "is ultimately legitimated by placing it within the context of a symbolic universe" (Berger \& Luckmann 1967:100). The latter is a "sheltering canopy" wherein both the institutional order and individual biography can be placed. It also provides the delimitation of social reality. It sets the limits to what is relevant in terms of social interaction. "The symbolic universe assigns ranks to various phenomena in a hierarchy of being, defining the range of the social within this hierarchy" (Berger \& Luckmann 1967:102). In Judean society, this hierarchy of being is now objectified in the purity order. The priests who function in the Temple have the highest degree of purity. Then comes the laity, proselytes and at the bottom are the "impure" (e g sinners and lepers), and entirely outside of this order are the Gentiles. Berger \& Luckmann (1967:103) further explain that the

symbolic universe also orders history. It locates all collective events in a cohesive unity that includes past, present and future. With 
regard to the past, it establishes a "memory" that is shared by all the individuals socialized within the collectivity. With regard to the future, it establishes a common frame of reference for the projection of individual actions. Thus the symbolic universe links men with their predecessors and their successors in a meaningful totality ... All the members of a society can now conceive of themselves as belonging to a meaningful universe, which was there before they were born and will be there after they die (emphasis original).

Naturally, once symbolic universes come into being, they require to be maintained. Various universe-maintenance procedures can be used. This is especially necessary when a society is confronted with another society that has its own history. In such instance an alternative symbolic universe comes into focus, with its own official traditions, which may judge one's own universe as ignorant, mad or the like. "The alternative universe presented by the other society must be met with the best possible reasons for the superiority of one's own" (Berger \& Luckmann 1967:108). This is especially true of Judeanism in its confrontation with Hellenism. Universe-maintenance can employ mythology, or more developed mythologies develop into more systematic theologies - Judeanism being a case in point!

Universe-maintenance also employs therapy and nihilation.

Therapy entails the application of conceptual machinery to ensure that actual or potential deviants stay within the institutionalized definitions of reality, or, in other words, to prevent the 'inhabitants' of a given universe from "emigrating" ... This requires a body of knowledge that includes a theory of deviance, a diagnostic apparatus, and a conceptual system for the "cure of souls".

(Berger \& Luckmann 1967:113)

In this regard, one is reminded of the Judean sacrificial cult and the practice of ritual immersion, according to which any form of deviance (sin or impurity) can be rectified. In this manner Judeans could maintain their position within the covenant, or the Judean symbolic universe.

"Nihilation, in its turn," is to "liquidate conceptually everything outside the same universe ... nihilation denies the reality of whatever phenomena or interpretations of phenomena [that] do not fit into that universe" (Berger \& Luckmann 1967:114). This can be achieved in one of two ways. Firstly, the phenomena are afforded a negative ontological status. It is regarded as inferior and should not be taken seriously. Secondly, deviant phenomena are grappled with theoretically in terms of concepts belonging to your own 
universe. Both these examples of nihilation are evident in Judeanism and are mutually complimentary. Gentile ways are regarded as inferior. Gentiles are guilty of idolatry and sexual immorality, in short, of "lawlessness". They are not part of the Judean symbolic universe, are not divinely elected, are ignorant of God's law, impure, ${ }^{5}$ and bereft of the truth.

The last element of the symbolic universe we shall discuss here is its maintenance by "experts". As more complex forms of knowledge appear, "they claim ultimate jurisdiction over that stock of knowledge in its totality". These universal experts "claim to know the ultimate significance of what everybody knows and does" (Berger \& Luckmann 1967:117). Now one of the consequences "is a strengthening of traditionalism in the institutionalized actions thus legitimated, that is, a strengthening of the inherent tendency of institutionalization toward inertia" (Berger \& Luckmann 1967:117). The Judean parallel is obvious in the existence of the priesthood and their control of the Temple and scribal training in the law. Other "expert groups" also appeared, such as the Pharisees and Essenes, for example.

The above served to illustrate how easily our redefined understanding of covenantal nomism can be understood as the Judean symbolic universe. It was the Judean social construction of reality that had to be maintained in the face of historical developments and Hellenistic and Roman ideology.

Covenantal nomism was therefore also the legitimation of Judean ethnic identity, where all Judean institutions, practices and beliefs were placed within the context of an all-embracing frame of reference. Within this universe people were told why they should do the things they did and why things are what they are. It bestowed meaning onto its "inhabitants", ordered reality into its proper place, and connected the "inhabitants" with their history, ancestors, and future generations and events.

\section{THE FOUR PILLARS OF SECOND TEMPLE JUDEANISM}

Another attempt at establishing a "common Judeanism", or at identifying that which was essential to Judeanism, was formulated by Dunn. Dunn (2003:281) takes into account the factionalism that existed in first-century Judeanism, but using our own terminology, he also speaks of the "four pillars of Second Temple Judeanism" (Dunn 1991:18-36; 2003:287-292). These include the Temple, God, Election and Torah, although Dunn admits that this is not a complete characterization of Judeanism. What follows is Dunn's proposal in abbreviated form.

\footnotetext{
${ }^{5}$ Originally Gentiles were not rated according to the degrees of purity, but as things developed, they were afforded an "impure status" because of their presence within the ancestral land of Israel (cf Sanders 1992:72-76; Schmidt 2001:241).
} 


\subsection{Temple}

The land of Israel was focused in the Temple, the central focus of Israel's national and religious life prior to its destruction in 70 CE (Dunn 2003:287). The Temple was 1) a political centre, the basis for the High Priest and high priestly families; 2) an economic centre, where the daily sacrifices and offerings were made and which required the payment of the annual Temple tax. It was also the focal point of the three main pilgrimage festivals; and 3) a religious centre, the place where God had chosen to put his name, the focal point for an encounter between the divine and the human, as well as the sacrificial cult on which human well-being and salvation depended (Dunn 1991:31-35).

\subsection{God}

"Belief in God", Dunn (2003:288) explains, "as one and in God's un-imageableness was certainly fundamental to the first-century [Judean]." Most Judeans probably said the Shema on a regular basis (Dt 6:4, 7), testifying to the unity of God (Ant 5.1, 27, 112). On the surface of late Second Temple Judeanism, little of this is apparent, simply because it was not a matter for controversy and could thus be taken for granted. Judeans were exclusive monotheists and Judean literature offers testimony of strong attacks on pagan, or rather Gentile idolatry (e g WisSol 11-15; SibOr 3:8-45). We need to recall Josephus' report of violent reaction from the people when Pilate introduced standards regarded as idolatrous to Jerusalem (Ant 18.55-59) and Caligula's attempt to have a statue of himself set up within the Temple (Ant 18.261-272).

\subsection{Election}

The notion of divine election was a fundamental aspect of Judean selfunderstanding. God had specially chosen Israel from among all the nations of the world to be his own (Dunn 2003:289). Election points to two features in particular: Israel as a covenant people and the Promised Land. This selection formed a mutual attachment between God and Israel through the covenant. It was the foundational motivation to resist Hellenistic syncretism in the Maccabean crisis, and "it constantly came to expression in the compulsive desire to maintain distinct and separate identity from the other nations" (cf Jub 15:30-32; 22:16) (Dunn 2003:289). So opposed to Hellenism stood

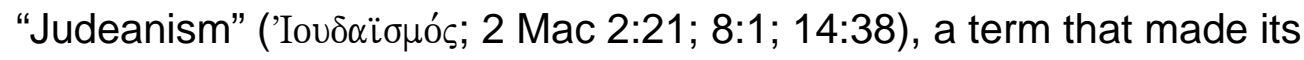
appearance around the time of the Maccabean revolt, and it "bears a clear overtone from its first usage of a fierce nationalistic assertion of Israel's election and of divine right to religious (if not national) freedom in the land given it by God" (Dunn 1991:22). 


\subsection{Torah}

The Torah was the focus of the covenant. The Torah (the first five books of Moses) had been given to Israel as a mark of God's favor and choice of Israel. It was an integral part of God's covenant with Israel, to show its people how to live as the people of God (Deuteronomy), or differently put, the commandments spell out Israel's covenant obligations. They were the people of the law/covenant, an identity that was at stake during the Maccabean crisis (1 Mac 1:57; 2:27, 50; 2 Mac 1:2-4; 2:21-22; 5:15; 13:14). Hence, understandably the watchword for national resistance during that period was "zeal for the law" (1 Mac 2:26-27, 50, 58; 2 Mac 4:2; 7:2, 9, 11, 37; 8:21). Generally there was a common pattern of "covenantal nomism" characteristic of Judeanism in our period (Dunn 1991:24-25). The Torah, the definitive element of the Scriptures, also served as both school textbook and as law of the land so "we may assume a substantial level of respect and observance of its principal regulations within common [Judeanism]" (Dunn 2003:291).

\section{JUDEAN CUSTOMS AS COVENANTAL PRAXIS}

In addition to the four pillars discussed above, it is to Dunn's credit that he realized the importance of customs or ritual practices to Judean selfunderstanding. In his studies on Paul's attitude towards the law in Galatians, Dunn has drawn on Sanders' notion of covenantal nomism and developed what is known now as a "new perspective". Paul, as Dunn explains, was not opposing a legalistic works-righteousness (e g see Ridderbos 1975:139-40) when some Judean Christians insisted on Gentiles undergoing circumcision or when they withdrew from having table-fellowship with them (GI 2). Paul was opposing specific covenant works, or "works of the law", namely circumcision and food laws. Why? Because "these observances were widely regarded as characteristically and distinctively [Judean]. Writers like Petronius, ${ }^{6}$ Plutarch, ${ }^{7}$ Tacitus $^{8}$ and Juvenal ${ }^{9}$ took it for granted that, in particular, circumcision, abstention from pork, and the Sabbath, were observances which marked out the practitioners as [Judeans], or as people who were very attracted to

\footnotetext{
${ }^{6}$ Cf Petronius, Satyricon 102.14; Fragmenta 37 on circumcision.

${ }^{7}$ Cf Plutarch, Quaestiones Conviviales 4.5; where he enters into a discussion to why Judeans do not eat pork.

${ }^{8} \mathrm{Cf}$ Tacitus (Histories 5.4) on the Sabbath. Dealing with circumcision, Tacitus writes: "They adopted circumcision to distinguish themselves from other peoples by this difference" (Histories 5.2). That Tacitus understands circumcision to be quite characteristic of Judeans should be noted for many other peoples (Samaritans, Arabs and Egyptians) also practiced circumcision.

${ }^{9} \mathrm{Cf}$ Juvenal (Satire $6.160 ; 14.98$ ) on abstention from pork and on the Sabbath (Satire 14.96106).
} 
[Judean] ways" (Dunn 1990:191-192; emphasis original). Dunn (1990:192) continues in that

\begin{abstract}
these observances in particular functioned as identity markers, they served to identify their practitioners as [Judean] in the eyes of the wider public, they were peculiar rites which marked out the [Judeans] as that particular people ... These identity markers identified [Judeanness] because they were seen by the [Judeans] themselves as fundamental observances of the covenant. They functioned as badges of covenant membership.
\end{abstract}

We can paraphrase the last sentence by saying that these observances, or examples of Judean customs, were badges of Judean ethnic identity. That is why Peter and Barnabas withdrew from table-fellowship with Gentiles. They could not resist that strong appeal to national identity and covenant faithfulness. These customs defined the boundaries of the covenant people, or Judean ethnic identity, that is why one could hardly claim to be a good Judean without observing these minimal observances. As Dunn explains, for a typical Judean of the first century $A D$, "it would be virtually impossible to conceive of participation in God's covenant [or read Judean ethnic identity], and so in God's covenant righteousness, apart from these observances, these works of the law" (1990:193; emphasis original). Therefore, what Paul was opposing was something similar to Sanders' notion of covenantal nomism, understood as pertaining to situations where God's grace extends only to those who wore those badges that marked out God's people. For Paul "the covenant is no longer to be identified or characterized by such distinctively [Judean] observances as circumcision, food laws, and Sabbath. Covenant works had become too closely identified as [Judean] observances, covenant righteousness as national righteousness" (Dunn 1990:197; emphasis original).

Against the background of our redefined understanding of covenantal nomism, Dunn's explanation of Paul's polemic becomes even clearer. Paul opposes a rigid attachment to covenantal nomism, an ethnic identity, but in the sense that God's mercy no longer is restricted to those who perform Judean customs that marked out that identity. But the important thing for our work lies in the highly prominent place that customs had in Judeanism as is evident in the polemics of the early Christian movement and the Judean literature of the period. Judeanism as a religion was more a matter of doing things than it being theology or faith. Ancient Judeanism had no creeds. Judean customs are important for they were related to covenant membership. From here on we deem it therefore appropriate, to refer to Judean customs as covenantal praxis. Covenantal praxis was a way to assert your covenant 
membership or ethnic identity, a way to affirm your participation in covenantal nomism, the Judean symbolic universe. Cohen (1987:61) explains that for Judeans and Gentiles

\begin{abstract}
the boundary line between [Judeanism] and paganism was determined more by [Judean] observances than by [Judean] theology. Josephus defines an apostate as a [Judean] who "hates the customs of the [Judeans]" or "does not abide by the ancestral customs." He defines a convert to [Judeanism] as a gentile who through circumcision "adopts the ancestral customs of the [Judeans]"10 ... For Philo too the essence of conversion is the adoption of the way of life of the [Judeans]. ${ }^{11}$
\end{abstract}

Schmidt expresses a similar viewpoint: "More than beliefs, multiple and debated, it is rites that weave the protective web of [Judean] identity" (Schmidt 2001:25; emphasis original). Although Judeanism "was defined more by its practices than its beliefs" (Cohen 1987:103), Judeanism certainly had a theological element to it, though. Proper action was ultimately grounded in proper belief. Nevertheless, if we want to understand Judean ethnic identity better, we will always have to remember that Judean identity, an ethnic identity which was profoundly religious, yes, was most visibly expressed through covenantal praxis. Covenantal praxis was covenantal nomism in action - it was simply about being a Judean, and it had very little, if anything to do with "legalistic works-righteousness".

\title{
6. ETHNICITY THEORY
}

The insight gained from the work of Sanders, Dunn, Berger and Luckmann, helpful as it may be, needs to be complimented with the insights of cultural anthropology, particularly ethnicity theory. Ethnicity theory is a relatively new form of science. The term "ethnicity" was not used until 1941, and only from the 1960's did it become a major social-scientific concept (Duling, 2005, p 3 of 30). The French word for an ethnic group, ethnie, is also used in English and is mainly found in social-scientific literature (Esler 2003:40). As it developed, two major theoretical approaches to ethnicity were proposed; namely, Primordialism and Constructionism (Duling, 2005, p 3 of 30). We shall first examine the former.

Primordialism, associated with Edward Shils (1957a; 1957b) and Clifford Geertz (1963), stresses that "ethnic groups are held together by "natural affections." These are bonds so compelling, so passionate, so

\footnotetext{
${ }^{10}$ Cf War 7.3.3.50; Ant 20.5.2.100 (on apostasy); Ant 20.17, 41 (on conversion).

${ }^{11}$ Cf Virtues 102-108.
} 
"coercive," and so overpowering, that they are fixed, a priori, involuntary, ineffable, even as "sacred." These bonds are deeply rooted in family, territory, language, custom, and religion." (Duling, 2005, p 3 of 30). They are, in a word, "primordial". In this instance one's ethnic identity "may not be so much a matter of choice, still less rational choice, but of tradition and emotions provoked by a common ancestry" (Esler 2003:45). This approach, much like constructionism, emphasizes the view of the participant, or how ethnic groups themselves understand reality (i e an insider or emic perspective). ${ }^{12}$ From an etic (or outsider) perspective, however, primordialism brings to attention the emotional and psychological strength of ethnic affiliation. It is thought that individuals acquire such primordial bonds "through early processes of socialization" and "such attachments have an overwhelming power because of a universal, human, psychological need for a sense of belongingness and self-esteem" (Jones 1997:66). Without a proper psychological explanation, a primordialist approach on its own can tend to be somewhat vague and deterministic. Ethnicity becomes an abstract natural phenomenon that is explained on the basis of "human nature", with little attention being given to the social and historical contexts in which ethnic groups are formed (Jones 1997:68-70).

Constructionism or the self-ascriptive approach to ethnicity, associated with Frederik Barth (1969), is the major alternative to primordialism. Constructionism argues that "ethnic identity is not inherent, fixed, or natural; rather, it is fluid, freely chosen, and thus can be seen to be perpetually constructed, that is, continually reconstructed" (Duling, 2005, p 3 of 30). The emphasis is not on the "cultural stuff" itself, though still important, but on the act of social boundary marking, or on how and why ethnic groups create and maintain group boundaries (Duling, 2005, p 3 of 30). In this case the boundary between an ethnic group and outsiders is more of a process than a barrier, thus "cultural features of the ethnic group are the visible and variable manifestation, but not the cause, of an ethnic boundary and identity .... [C]ultural indicia might change over time and yet the ethnic group could still retain a sense of its own distinctiveness" (Esler 2003:42-43). Therefore, in this approach it is important to remember that cultural features do not constitute, but signal ethnic identity and boundaries. An ethnic identity is maintained but with no necessary relation to specific cultural content - the ethnic identity is

\footnotetext{
${ }^{12}$ According to Esler, however, primordial attachments is a notion where "we are able to draw the standard anthropological distinction between the emic (insider or indigenous) and the etic (outsider or social-scientific) points of view" (Esler 2003:46). What Esler points to here is the need for an etic apparatus set at a reasonably high level of abstraction, yet the definition of ethnicity is plagued by the nature of ethnicity itself: "Are ethnic groups based on shared 'objective' cultural practices and/or socio-structural relations that exist independently of the perceptions of the individuals concerned, or are they constituted primarily by the subjective processes of perception and derived social organization of their members?" (Jones 1997:57).
} 
self-ascriptive, continuously renewed and renegotiated through social practice (Esler 2003:42, 47). Constructionists also claim that groups construct their ethnic boundaries in two major ways: firstly "in relation to like-minded, likepracticed peers, a 'we' aggregative self-definition" and secondly, "in relation to others, a 'we-they' oppositional self-definition". The latter is usually ethnocentric (Duling, 2005, p 4 of 30). ${ }^{13} \mathrm{~A}$ development based on constructionism is instrumentalism, where an ethnic group's self-construction is rational and self-interested and deliberately mobilized in an attempt to further its own political-economic agenda (Duling, 2005, p 3 of 30; Esler 2003:46).

Another approach to ethnicity, which is also relevant in this regard, is ethno-symbolism. This approach analyses how an ethnic group's nostalgia about its perceived past - expressed through cosmogonic myths, election myths, memories of a golden age, symbols - shapes the group's ability to endure, but also to change and adapt (Duling, 2005, p 4 of 30). This can be seen in Judean literature (e g Jubilees and Pseudo-Philo) where past traditions are used creatively for the Judean struggle against Hellenism and the maintenance of the Judean symbolic universe.

Overall, the constructionist (or self-ascriptive) approach has become the dominant theoretical perspective on ethnicity (Duling, 2005, p 4 of 30; Esler 2003:47). Jones (1997:84) explains that

from the late 1960s onwards the dominant view within "western" social scientific traditions has been that ethnic groups are "self-defining systems" and consequently particular ethnic groups have been defined on the basis of self-identification and identification by others. Such a definition has largely been set within a theoretical framework focusing on the construction of ethnic boundaries in the context of social interaction and their organizational properties. Ethnicity has been regarded as essentially a consciousness of identity vis-à-vis other groups; a "we"/"they" opposition.

There is, unfortunately, to date no "grand unified theory" with regard to ethnicity. There have been attempts to integrate the various approaches and there is widespread recognition among social scientists that some form of reconciliation between the constructionist approach and the continuing importance of primordial dimensions of ethnicity is necessary (Esler 2003:46). Duling (2005, p 4 of 30) also explains that most theorists agree that people ascribe ethnicity to themselves (constructionism), but they disagree on whether self-constructed ethnicity is "irrational and ineffable" (primordialist) or

\footnotetext{
${ }^{13}$ We would like to add by stating that these two forms of self-definition are equally appropriate in a primordialist context.
} 
"rational and self-interested" (instrumentalist). In this regard Esler (2003:48) argues that "either option [i e instrumentalism or primordialism] is possible but that local and individual circumstances will affect which mode is in action at any particular time ... [W]e need to be open to the possible stubbornness of ethnic affiliation, while not underestimating the power of individuals and groups to modify ethnic identity for particular social, political, or religious ends." It is also suggested that both perspectives are continuously present, but to varying degrees (Jones 1997:80). A constructionist approach is thus the underlying form with either an instrumentalist or primordialist overlay given as alternatives.

Although Esler (2003:46) accepts that generally a constructionist approach to ethnicity is the dominant one amongst social scientists, he also explains, however, that "members of an ethnic group, particularly one under threat, are far more likely to adhere to a primordialist view of ethnicity" than to an interactive and self-ascriptive (constructionist) approach, and even less to an instrumentalist one. Here constructionism/instrumentalism and primordialism are basically viewed as alternatives with emphasis placed on primordialism. Perhaps it is better to conclude that the historical context of an ethnic group will dictate how we approach their ethnic identity.

Jones (1997:87-105) has attempted a theoretical approach which she suggests overcomes the primordialist and instrumentalist dichotomy. Her own approach thus falls in line with the broad consensus where constructionism is the underlying perspective. At the outset she draws attention to Bourdieu's theory of practice which develops a concept known as the habitus:

The structures constitutive of a particular type of environment ... produce habitus, systems of durable, transposable dispositions, structured structures predisposed to function as structuring structures, that is, as principles of generation and structuring of practices and representations which can be objectively "regulated" and "regular" without any way being the product of obedience to rules.

(Bourdieu 1977:72; emphasis original)

The habitus therefore is "made up of durable dispositions towards certain perceptions and practices" that "become part of an individual's sense of self at an early age, and which can be transposed from one context to another ... As such, the habitus involves a process of socialization whereby new experiences are structured in accordance with the structures produced by past experiences, and early experiences retain a particular weight" (Jones 1997:88). But interestingly, the habitus are both "structuring structures" and 
"structured structures", which shape, and are shaped by social practice (Jones 1997:89). Jones then draws attention to the work of Bentley, who draws on Bourdieu's theory of practice to develop a practice theory of ethnicity, which for Jones (1997:90) provides an objective grounding for ethnic subjectivity:

\begin{abstract}
According to the practice theory of ethnicity, sensations of ethnic affinity are founded on common life experiences that generate similar habitual dispositions ... It is commonality of experience and of the preconscious habitus it generates that gives members of an ethnic cohort their sense of being both familiar and familial to each other.
\end{abstract}

(Bentley 1987:32-3)

Thus, "it can be argued that the intersubjective construction of ethnic identity is grounded in the shared subliminal dispositions of the habitus which shape, and are shaped by, objective commonalities of practice ... The cultural practices and representations that become objectified as symbols of ethnicity are derived from, and resonate with, the habitual practices and experiences of the people involved, as well as reflecting the instrumental contingencies and meaningful cultural idioms of a particular situation" (Jones 1997:90). Hence the cultural features employed by an ethnic group are neither purely primordialist (irrational and ineffable) nor purely instrumentalist (rational and self-interested), but a combination of both. Jones then continues to adapt Bentley's theory, as far as we can identify, in three major ways.

Firstly, a shared habitus does not necessarily lead to feelings of ethnic affinity. The opposite is also true. Differences in habitus do not exclude identification. What is important here is the role played by the "ethnic others" in the construction of ethnicity - ethnicity is essentially a consciousness of difference vis-à-vis others, not merely a recognition of similarities. Thus loosely affiliated groups of people who nevertheless have commonalities of practice and experience may band together in opposition to outside cultures. European colonialization of African peoples is a case in point (Jones 1997:9395). A second, but related issue is that in "some situations there may be a high degree of contiguity between ethnicity and the habitus, whereas in other situations characterized by social dislocation and subordination there may appear to be very little" (Jones 1997:97). So ethnic identities also encode relations of power. Ethnicity can form the basis of political mobilization and resistance. That being the case, subordinated minority ethnic groups of diverse origins can for example form a collectivity as a result of large scale urban migration. With time cultural realties and relationships of inequality will 
lead "to their incorporation as part of the structured dispositions of the habitus" (Jones 1997:97; cf Stein 2004). Thirdly, the manifestation of a particular ethnic identity may also vary in different social and historical contexts. "For instance, the institutionalization of ethnicity in the modern nation-state and its representation in national politics, is likely to be qualitatively different from the activation of ethnicity in the processes of interaction between members of a local community or neighborhood" (Jones 1997:99).

Thus the concept of the habitus is overall broadened by Jones. Bentley's notion of the habitus draws on the theory of Bourdieu, which reflects the situation of a highly integrated and uniform system of dispositions characteristic of a small scale society. Yet, this does not properly explain highly differentiated and complex societies. "Ethnicity is a multidimensional phenomenon constituted in different ways in different social domains. Representations of ethnicity involve the dialectical opposition of situationally relevant cultural practices ... Consequently there is rarely a one-to-one relationship between representations of ethnicity and the entire range of cultural practices and social conditions associated with a particular group." What we end up with, from a bird's eye view that is, is "one of overlapping ethnic boundaries constituted by representations of cultural difference, which are at once transient, but also subject to reproduction and transformation in the ongoing processes of social life" (Jones 1997:100). To summarize, Jones' (1997:128-129) approach to ethnicity, it can be paraphrased as follows:

- The construction of ethnicity is grounded in the habitus - the shared subliminal dispositions of social agents - which shape, and are shaped by, objective commonalties of practice. The habitus provides the basis whereby common sentiments and interests are recognized and cultural affinity and difference are perceived and communicated.

- As a result, the primordialist and instrumentalist dichotomy can be overcome. The cultural practices that become objectified as symbols of ethnicity both derive from and resonate with habitual practices and experiences of the people in question, but also reflect the instrumental contingencies of a particular situation.

- Ethnicity is not always congruent with the habitus or the cultural practices of a group. Very importantly, ethnic identity involves an objectification of cultural practices in the recognition and communication of difference in opposition to others. The extent to which ethnicity is grounded in a pre-existing habitus or cultural realities 
is highly variable and dependent on prevailing social conditions, that is, the nature of interaction and the power relations between groups of people.

- Hence cultural practices that communicate the "same" identity may vary in different social contexts subject to different social conditions. Rarely will there be a one-to-one relationship between representations of ethnicity and the entire range of cultural practices and social conditions relevant to a particular ethnic group. Rather, one finds a pattern of overlapping ethnic boundaries, which are produced by context-specific representations of cultural difference. The latter is transient, but also subject to reproduction and transformation in the ongoing processes of social life.

Much, but not everything of what has been stated above, explains first-century Palestinian Judeanism. For example, we seriously question whether the broadening of the habitus and the idea of "overlapping ethnic boundaries" are that applicable. Admittedly, such a distinction is relevant when taking into account that Judeans lived in Judea, Galilee and the Diaspora, in both rural and urban settings, and that a minority of Judeans belonged to sectarian groups. These diverse social contexts are, however, offset by the nature of Judeanism itself. This is where we need to draw attention to Berger and Luckmann's notion of the "symbolic universe", which nevertheless, shows much affinity with Jones' approach outlined above. Just as human beings both shape, and are shaped by an objective society (i e institutions derived from habitual actions), so the habitus (subliminal and habitual dispositions) both shape, and are shaped by objective common cultural practices. However, Berger's notion of the symbolic universe adds important dimensions. It involves the human search for meaning, combined with the theory that the institutional order is integrated into an all-embracing frame of reference, first century Judeanism being exemplary of such an approach. The point is this: the overwhelming majority of Judeans, in this instance focusing on those who lived in Palestine in particular, were informed and shaped by the same symbolic universe, indeed similar habitus, relevant to every social and historical context due to the all-encompassing and permanent nature of the covenant. Admitting certain peculiarities, their beliefs and cultural practices, as they related to a shared symbolic universe were, to a large degree, homogenous. The same identity was communicated by similar beliefs and cultural practices in different social contexts. Most certainly the dimensions of belongingness and self-esteem also come into play here. The implications are 
that we understand Judeanism as a highly integrated and uniform system of dispositions, but more about our understanding of Judean ethnicity later when we explain our proposed model.

Naturally, people give expression to their ethnicity through various cultural features, although not all of them are required for ethnic formation. Ethnicity theory has broadly recognized several cultural features that are important for ethnic identity. The cultural features include the following: 1) name, a corporate name that identifies the group; 2) myths of common ancestry, the group claims to be descendents of a particular person or group/family; 3) shared "historical" memories, the group points to common heroes and events of the past; 4) land, the group has actual or symbolic attachment to an ancestral land; 5) language, or local dialect; 6) kinship, members of the group belong to family units which in turn, demonstrate communal solidarity with the local community or tribe, and with the group as a national entity; 7) customs identifiable with that group; and 8) also its religion. To this list 9) phenotypical features, which point to genetic features (Duling, 2005, p 4 of 30; Esler 2003:43-44) could be added, although not relevant for our purposes here (as Judeans basically looked like everybody else in the Roman-Hellenistic world).

Duling in turn developed a model that lists these key representative socio-cultural features that could influence an ethnie's values, norms and behavior. He describes it as an outsider's model (etic model) that is "imposed" on the available data. Duling (2005, pp 4-5 of 30) further describes it as a "socio-cultural umbrella" that highlights "cultural stuff" but the broken lines and temporal arrow (see graphic) attempt to allow for the dominant constructionist approach in ethnicity theory. Duling's model, he admits, runs the risk of oversimplifying distinctive historic or local ethnographic information, but Duling regards his model as heuristic; it is open to criticism and modification or, if necessary, even reconstruction. Meanwhile, any discussions of ethnicity can look out for such features in ancient literature (Duling, 2005, p 5 of 30). It is also important to note that the most widespread of these features are kinship relations, myths of common ancestry and some connection with a homeland (Duling, 2005, p 4 of 30; cf Esler 2003:44). Duling's model is as follows: 


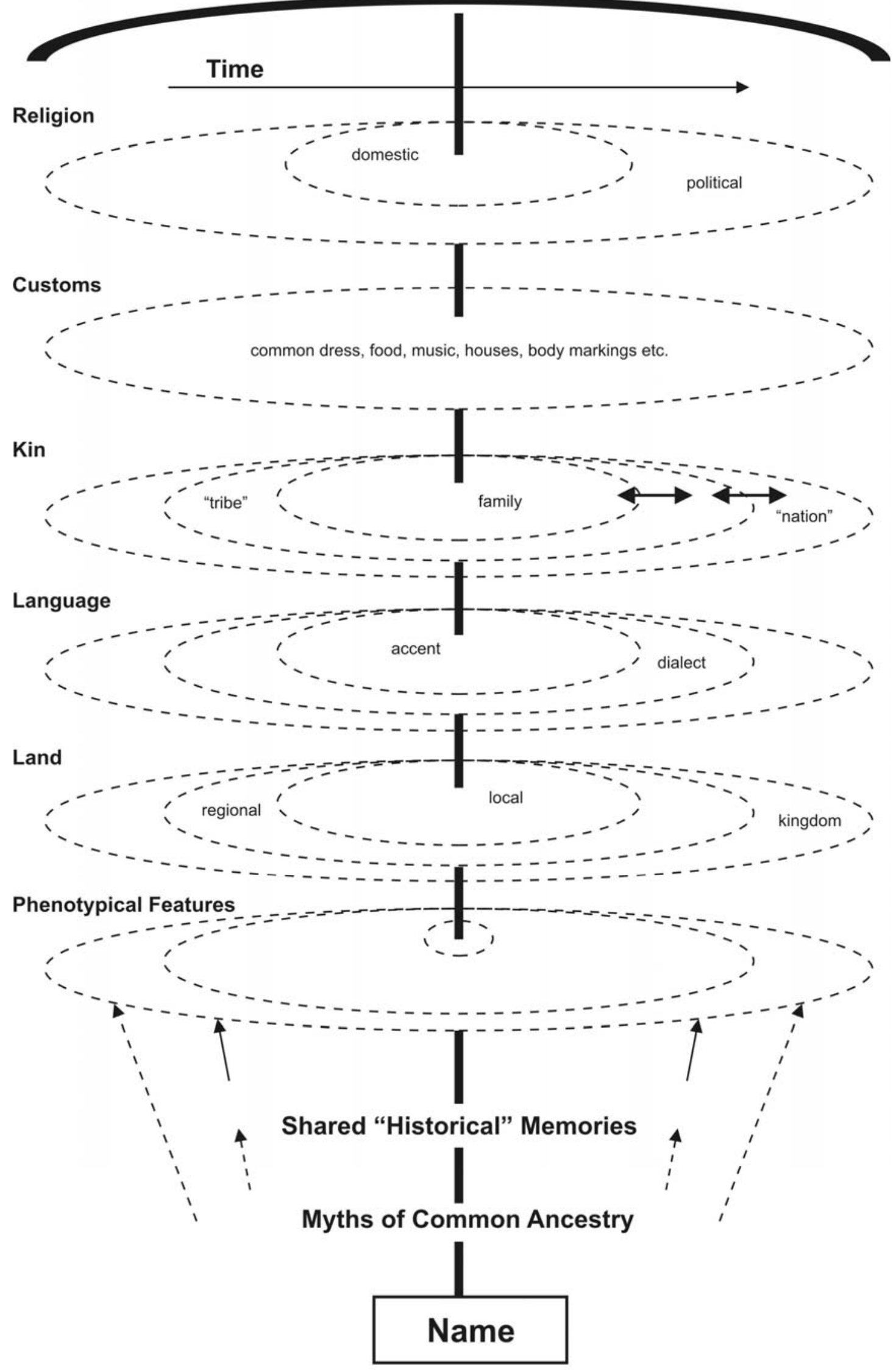

D C Duling's Socio-Cultural Model of Ethnicity 
Are these cultural features found in Duling's model evident in ancient literature? The answer is "yes". It becomes evident that ancient peoples were recognized by their name, language, ancestry, customs and religion to name but a few (cf Herodotus, Histories 8.144.2; Strabo, Geography 1.2.34; Gn 9:26; 10:31). It is therefore by no means inappropriate to apply modern ethnicity theory to ancient peoples (cf Duling, 2005, p 6 of 30; Esler 2003:53).

\section{THE SOCIO-CULTURAL MODEL OF JUDEAN ETHNICITY: A PROPOSAL}

At this stage, all of the above can be put together into our own proposal on how a more comprehensive understanding of the dynamics of Judean ethnic identity can be achieved. The proposed model below is a synthesis of covenantal nomism when redefined as an ethnic descriptor, Berger \& Luckmann's notion of a "symbolic universe", Dunn's "four pillars" and his "new perspective" on Paul, the insights of ethnicity theory and Duling's SocioCultural Model of Ethnicity. It must also be understood that our proposed model is attempting to establish guidelines for a mainstream or common Palestinian Judeanism. Our proposed model is as follows: 


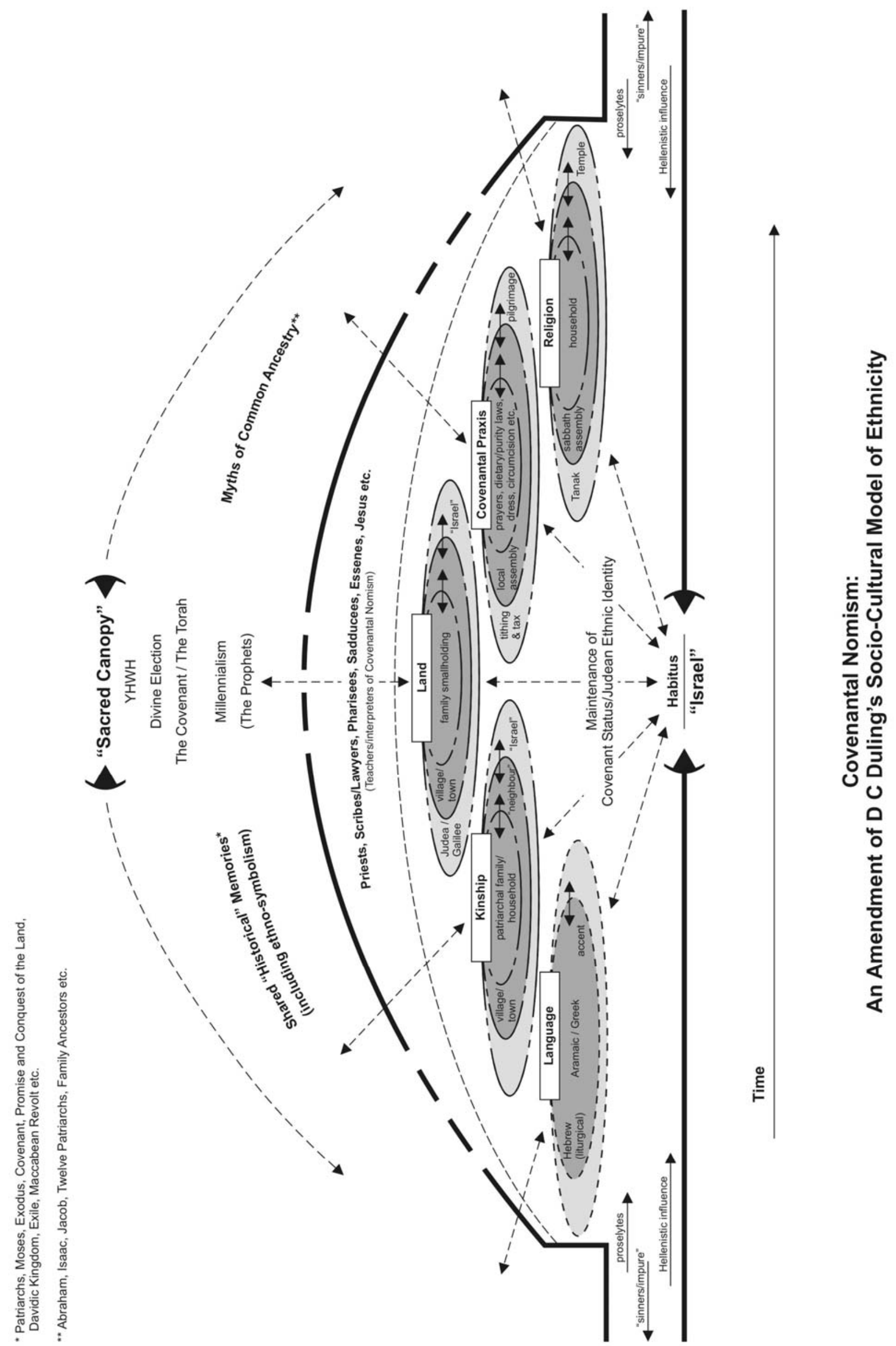


Our socio-cultural model of Judean ethnicity admittedly is a modern construct, as Duling put it, "imposed" on the available data. The model bears the appropriate name of "Covenantal Nomism". The name describes the entire process of Judean ethnic identity formation in a nutshell. It constitutes the Judean social construction of reality, their "symbolic universe". We attempted to represent this aspect in the model, which admittedly, entailed a relatively high degree of abstraction. The model consists mainly of two areas, namely, the "Sacred Canopy" and the "Habitus/Israel". The "Sacred Canopy" is primarily the dimension in the model dealing with God who established (in the past), and continues to prescribe (in the present), Judean ethnicity through his divine election, the covenant, and gift of the Torah ("getting in"). The "Habitus/Israel" (which extends to include more tangible cultural features), refers to a group of people, Israel, responding to that call by being Judean ("staying in"). We shall first discuss the Habitus/Israel in further detail.

\subsection{The Habitus/lsrael}

Judean ethnicity is grounded in the habitus, the shared habitual dispositions of Judean social agents, or in short, "Israel", which shape and are shaped by objective common cultural practices. The Habitus/Israel primarily constitutes the dialectical interrelationship between the habitus and the more tangible institutions or cultural features of Judean ethnicity, which collectively, is contained within the thick black lines. This interrelationship is dominated by the endeavor to respond to God's divine election and to maintain covenant status or Judean ethnic identity ("staying in"). Being grounded in the habitus, the interrelationship produces Judean ethnic identity, which involves the objectification of cultural practices in the recognition and communication of affinity and difference vis-à-vis other peoples. In this regard, the identity of the individual, and his/her sense of belongingness and self-esteem, and ability to find his/her place within the Judean symbolic universe also constitute an important element.

As has already been mentioned, ethnicity theory explains that kinship relations and myths of common ancestry and a certain connection with a homeland are the most widespread of the cultural features. We have given some prominence to the cultural feature of land in our model, as it has always been a primary feature of Judean ethnicity, and is related to the very strong hopes of restoration the Judeans had (i e "Millennialism"). Land is flanked by kinship and covenantal praxis (which stand in close association with religion) and which in their own way were also primary sources of identity. But overall, the Habitus/Israel points to Judeans living on their land, circumcising their 
sons, eating food according to the laws of kashrut, going on pilgrimage, their family ties and communal solidarity and attending the Sabbath assembly and so on. It points to covenantal nomism in action.

The above explains the dialectic relationship between the Habitus/Israel and the immediate cultural features that gave expression to that ethnic identity. Importantly, it is our argument that the predominant constructionist approach to ethnicity does not properly explain first-century Palestinian Judeanism. Duling's predominantly constructionist approach, represented by the broken lines in his model, is replaced by our predominantly primordialist approach, represented by the more solid lines. It is our contention that when it came to ethnic identity formation, the Judeanism of our period was essentially primordialist. Many constructionist elements are secondary, and in fact, are based on or derived from a primordialist approach to ethnicity. Esler (2003:69) has argued, however, that during the period from the 530s BCE to $100 \mathrm{CE}$, the Judeans "maintained a strong sense of identity in relation to outsiders in spite of radical changes in the cultural features by which that separation was expressed" (emphasis added). Unfortunately, Esler does not explain what those "radical changes" in the cultural features are. Although not denying that there were some constructionist elements to Judean ethnicity (see below), we must ask whether the argument for radical change is not exaggerating the evidence? - or is Esler compelled to be faithful to the predominant approach of ethnicity theory? We base our understanding of Judean ethnicity as being essentially primordialist on two important reasons.

First, Judeanism was primordial, not in the sense that it was deterministic or "natural", but was conditioned, or "determined" by the inherent nature of the Judean symbolic universe (= our redefined covenantal nomism) itself. The Judean symbolic universe had one mandate only: Perpetually regenerate thyself! As we have argued earlier, we understand Judeanism as a highly integrated and uniform system of dispositions. For this reason, Judean ethnicity was highly congruent with the habitus and established cultural practices. Differently put, covenantal nomism reproduced covenantal nomism. The reason for this is that its ways were pretty much set according to the requirements of the covenant and Torah. It did not have the "freedom" to construct its culture as other ethnic groups had. Being God's elect people therefore had its restrictions, relevant to all social contexts and opposing interactions. Hence, the constructionist idea that "cultural features of the ethnic group are the visible and variable manifestation, but not the cause, of an ethnic boundary and identity" (Esler 2003:42) is hardly applicable to Judeanism. Judean cultural features were basically "permanent" and therefore 
inseparable from Judean ethnic identity. Therefore in themselves, Judean cultural features were the cause of a rigid and tenacious ethnic boundary and identity in addition to the aspect of social organization.

Secondly, Judeanism formed part of the Roman Empire; hence it was the victim of political and economic oppression and exploitation. Esler (2003:46) himself noted that members of an ethnic group, particularly one under threat, are far more likely to adhere to a primordialist view of ethnicity. A related feature is that Judeanism was under pressure from Hellenism - at one stage it was even persecuted and forced to adopt Hellenistic culture (Maccabean revolt). Judeanism was fighting back to preserve its identity and distinctiveness, although it did not remain impervious to Hellenistic influence. It must be recalled that ethnic identities also encode relations of power (Jones 1997:97). Judean ethnicity encoded an identity in which reality conflicted with the ideal, in which a dominated people longed for divine deliverance. Overall the literature of the period makes varied use of ethno-symbolism to help the Judean people endure and to help them remember who they are; people of the covenant, and a people who are called to obedience to God's commandments.

Where a constructionist approach is relevant, three examples will be discussed here. Firstly, the laws on clean and unclean foods do not hold such a central place in the Torah (Lv 11:1-23; Dt 14:3-21). From the time of the Maccabees, however, they took on increasing importance in Judean folklore and Judean self-understanding (Dunn 1990:193). As regards the devout the impure food of Gentiles or non-observant Judeans had to be avoided at all cost. Secondly, in post-exilic Israel Gentiles could now also convert to Judeanism, while intermarriage was prohibited. For a Gentile woman, marriage to a Judean man was a de facto equivalent of conversion (Cohen 1987:51, 54). Conversion required the severing of all your previous ethnic and religious roots. These two examples, however, corroborate our suggestion that many constructionist elements of Judeanism had its basis in primordialism. We consider it self-explanatory that these two developments in various ways were more a result of strong emotional bonds rooted in family, territory, language, custom and religion (cf Duling, 2005, p 3 of 30).

A third example is an exception to the above. It concerns the cultural feature of language. When viewing our model, it is noticeable that it is the only cultural feature that is represented by broken lines, indicating that it was a cultural feature in (re)construction. It is commonly accepted that Aramaic was the everyday spoken language of Palestinian Judeans, but based on the available evidence more and more Judeans spoke Greek, as a second, or even as a first language. The use of Hebrew, the Judean language proper, 
surprisingly was not at all as widespread as the other languages. The adoption of the Greek language was in no way a reinforcement of primordialism, but even here, some form of primordialism existed as the Judean scriptures were translated into Greek, and Judean apologists wrote their works in Greek as well, often adopting Hellenistic forms. At the same time it must be said that speaking the Greek language did not seem to undermine one's ethnic identity. Thus the cultural feature of language was not an important factor for determining Judean ethnicity.

A convenient way of analyzing an ethnic group is also by differentiating between the varying perspectives of those involved with the group. Thus besides looking at the issues of primordialism or constructionism, the processes of ethnic identity formation can also be modeled on three separate though connected levels of abstraction: micro, median and macro (Esler 2003:48-49). Briefly, the micro level is concerned with processes that affect the ordinary members of the group. Its focus is on individual persons and interpersonal interaction. The median level is concerned with the leaders of the group. In this instance processes create and mobilize groups and intervene to constrain or compel people's expression and action on the micro level. Lastly, the macro level concerns itself with outsiders with power over the group. It is the apparatus (ideological, legal, and administrative framework) of the state that allocates rights and obligations. We attempted to model the processes of Judean ethnic identity formation onto the micro and median (darker grey) and macro (lighter grey) level. By representing the micro and median level with the same color, we attempted to show how closely connected these two levels are in Judean society. The individual, and interpersonal relationships occurred mostly within the family and local community, and the local community leaders mobilized action or enacted decisions applicable on the micro level. The macro level is where the Temple state directly exercised influence and authority. A group such as the Pharisees, floating somewhere in the middle, attempted to gain influence in both the micro-median and the macro level.

Lastly, there were those Judeans, predominantly the priesthood, who along with others, acted as teachers or interpreters of covenantal nomism. They were the "experts" whose main task was the maintenance of the Judean symbolic universe. They were the link between the Sacred Canopy and the Habitus/lsrael. The historical Jesus functioned here as well.

\subsection{The Sacred Canopy}

The second main part of our model concerns the "Sacred Canopy". For lack of a better description, it constitutes the Judean "religion" or "theology". The 
habitus not only shapes, and is shaped by common cultural practices, but they also shape and are shaped by Israel's common beliefs; that is the "Sacred Canopy". This dialectical interrelationship primarily has to do with the belief that Yahweh established/prescribes Judean ethnicity ("getting in"). It therefore also involves the recognition and communication of affinity and difference visà-vis other peoples. As such the sacred canopy represents the more "intangible" aspects of Judean ethnicity, or the furthest reach of Judean selfexternalization (cf Berger 1973:37).

\begin{abstract}
Religion legitimates social institutions by bestowing upon them an ultimately valid ontological status, that is, by locating them within a sacred and cosmic frame of reference ... Israel legitimated its institutions in terms of the divinely revealed law throughout its existence as an autonomous society ... Religious legitimation purports to relate the humanly defined reality to ultimate, universal and sacred reality. The inherently precarious and transitory constructions of human activity are thus given the semblance of ultimate security and permanence.
\end{abstract}

(Berger 1973:42, 44; emphasis original)

The sacred canopy concerns that part of covenantal nomism under which all of the system or identity we call Judeanism took shape. It is that construct under which the entire Judean institutional order is integrated into an allembracing and sacred frame of reference. It was that externalization that informed the overall Judean self-concept. And importantly, the "religious enterprise of human history profoundly reveals the pressing urgency and intensity of man's quest for meaning. The gigantic projections of religious consciousness ... constitute the historically most important effort of man to make reality humanly meaningful, at any price" (Berger 1973:106-7).

As was previously mentioned, in pre-modern eras a distinctive religion or vision of a world religion proved to be a very strong force in the persistence of ethnic identity. In this regard the sacred canopy points first and foremost to Yahweh, the God of Israel and his election of that people, the covenant and gift of the Torah. Collectively, these most definitively constituted a strong force in the persistence of Judean ethnic identity. Inseparable from this, however, are shared "historical" memories and the rich ethno-symbolism contained therein, and the myths of common ancestry. All of these together constitute an example of a communal mythomoteur, or constitutive political myth of an ethnie (see Smith 1994:716). The community is endowed with sacred qualities, "which may generate an almost messianic fervor in times of crisis, 
particularly when allied to a heightened sense of superiority and a myth of ethnic election" (Smith 1994:716).

The latter naturally leads into the last element of the furthest reach of Judean self-externalization, namely, Millennialism. Inspired by the prophets, and no doubt contemporary reality, Israel was awaiting God's intervention on their behalf. The future restoration of Israel primarily referred to Israel's independent control and ownership of the land. Through divine intervention the Judean symbolic universe was to be made complete.

\subsection{Summary}

Thus the above is a presentation of our proposed model and a basic explanation for the rationale behind it. The socio-cultural model of Judean ethnicity is a pictorial and abstract representation of the Judean symbolic universe, which we have termed covenantal nomism. It consists of the Habitus/Israel, which stand in a close interrelationship with the more tangible Judean cultural features. The habitus, or habitual dispositions of Judean social agents, both shape and are shaped by objective common cultural practices. At this level Judeans, by being Judean, by maintaining their covenant status or Judean ethnic identity (by "staying in") are responding to Yahweh's divine election. The Sacred Canopy is the furthest reach of Judean self-externalization, under which all Judean institutions or cultural features are placed within a sacred and all-embracing frame of reference. The habitus, also shape and are shaped by common beliefs, including a common history and ancestry. The Judean belief that Yahweh established/prescribes Judean ethnicity ("getting in") can be found at this level. There is also a future element to it, in that Israel was hoping for future restoration. Collectively, being grounded in the habitus, the two dialectic interrelationships produce Judean ethnic identity, which involves the objectification of cultural practices in the recognition and communication of affinity and difference vis-à-vis other peoples.

The model as outlined and explained above, we do not regard as definitive or final. Similarly to Duling, we regard it as heuristic; it should be changed or reconstructed as needed. It therefore also runs the risk of oversimplifying historic or local ethnographic information. We do, however, suggest, that it could serve as a useful guideline to determine and investigate common Judean ethnicity and to determine instances where Judeans are "deviant" from the norm. 


\section{Works consulted}

Barth, F 1969 (ed). Ethnic groups and boundaries. Boston: Little \& Brown.

BDAG 2000. A Greek-English Lexicon of the New Testament and other Early Christian literature, $3^{\text {rd }}$ ed of BAGD, rev by F W Danker. Chicago, IL: University of Chicago Press.

Bentley, G C 1987. Ethnicity and practice. Comparative Studies in Society and History 29, 24-55.

Berger, P L 1973. The social reality of religion. Harmondsworth: Penguin University Books.

Berger, P L \& Luckmann, T 1967. The social construction of reality: A treatise in the sociology of knowledge. New York: Anchor Books.

Bourdieu, P 1977. Outline of a theory of practice. Cambridge: Cambridge University Press.

Chilton, B \& Neusner, J 1995. Judaism in the New Testament: Practices and beliefs. London: Routledge.

Cohen, S J D 1987. From the Maccabees to the Mishnah. Philadelphia, PA: Westminster.

Cohen, S J D 1990. Religion, ethnicity, and Hellenism in the emergence of Jewish identity in Maccabean Palestine, in Bilde, $\mathrm{P}(\mathrm{ed})$, Religion and religious practice in the Seleucid kingdom, 204-23. Aarhuis: Aarhuis University.

Cohen, S J D 1999. The beginnings of Jewishness: Boundaries, varieties, uncertainties. Berkeley, CA: University of California.

Duling, D C 2005. Ethnicity, ethnocentrism, and the Matthean ethnos. Forthcoming in BTB 35(4), 125-143.

Dunn, J D G 1990. Jesus, Paul and the law: Studies in Mark and Galatians. Louisville, KY: Westminster John Knox.

Dunn, J D G 1991. The partings of the ways between Christianity and Judaism and their significance for the character of Christianity. London: SCM Press.

Dunn, J D G 2003. Christianity in the making: Jesus remembered. Grand Rapids, MI: Eerdmans.

Du Toit, D S 2001. Redefining Jesus: Current trends in Jesus research, in Labahn, M \& Schmidt, A (eds), Jesus, Mark and Q, 82-124. Sheffield: Sheffield Academic Press.

Esler, P F 2003. Conflict and identity in Romans: The social setting of Paul's letter. Minneapolis, MN: Fortress Press.

Geertz, C 1963. The integrative revolution: Primordial sentiments and civil politics in the new states, in Geertz, C (ed), Old societies and new states, 105-57. New York: The Free Press.

Harrington, D J 1987. The Jewishness of Jesus: Facing some problems. CBQ 49, 113.

Holmén, T 2001. The Jewishness of Jesus in the "Third Quest', in Labahn, M \& Schmidt, A (eds), Jesus, Mark and Q, 143-162. Sheffield: Sheffield Academic Press.

Jones, S 1997. The archaeology of ethnicity: Constructing identities in the past and present. London: Routledge.

Pilch, J J 1997. Are there Jews and Christians in the Bible? HTS 53, 119-125. 
Ridderbos, H 1975. Paul: An outline of his theology, tr by J R De Witt. Grand Rapids, MI: Eerdmans.

Sanders, E P 1977. Paul and Palestinian Judaism: A comparison of patterns of religion. London: SCM.

Sanders, E P 1992. Judaism: Practice and belief 63 BCE-66 CE. London: SCM.

Schmidt, F 2001. How the temple thinks: Identity and social cohesion in Ancient Judaism. tr by J E Crowley. Sheffield: Sheffield Academic Press.

Shils, E A 1957a. Center and periphery: Essays in macrosociology. Selected papers of Edward Shils, vol 2, 111-26. Chicago, IL: Chicago University Press.

Shils, E A 1957b. Primordial, personal, sacred and civil ties. British Journal of Sociology 8, 130-45.

Smith, A D 1994. The politics of culture: Ethnicity and nationalism, in Ingold, T (ed), Companion Encyclopedia of Anthropology, 706-33.

Stegemann, E W \& Stegemann, W 1999. The Jesus movement: A social history of its first century, tr by O C Dean. Edinburgh: T\&T Clark.

Stein, S 2004. s v Ethnicity. Encyclopedia of Race and Ethnic Studies, 142-46. 